\title{
Characterization of the Zellidja Lead Smelter Slag (Eastern Morocco) in order to their Valorization in Civil Engineering
}

\author{
Raja Moussaoui 1*, Souad EL Moudni EL Alami', Hassan Aouraghe ${ }^{1}$ \\ 1 Laboratory of Applied Geosciences, Faculty of Sciences, Mohammed First University, BV Mohammed VI, P.O. \\ Box 524, 60000 Oujda, Morocco \\ * Corresponding author's e-mail: raja.moussaoui.91@gmail.com
}

\begin{abstract}
The Zellidja Lead Smelter Company (Eastern Morocco) was created by Jean Walter in 1939 for the purpose of transforming lead concentrates into pure metal. Its activity was always at the origin of the production of huge quantities of solid mining waste with granular aspect. Today, despite the definitive cessation of its production in 2012 due to the depletion of ore, millions of tons of slag are piled up between the back of the foundry and the watercourse of Oued El Heimer. This open-air storage site represents a significant environmental and economic risk resulting from the surface water and groundwater pollution. In addition, as part of the strengthening of the Moroccan construction sector and infrastructure (which requires enormous quantities of natural aggregates), studying the possibilities of using these by-products as building materials seems interesting. For these reasons, the objective of our research work is the characterization of Zellidja slag for their valorization in civil engineering. This valorization has three objectives: to solve the problem of the landfill of the mining waste, to search for an alternative material responding to the increased needs for granular materials and to protect the national patrimony in raw material. In order to ensure the feasibility of this valorization, these tailings were the subject of a complete characterization. The results of this characterization prove that these by-products with a granular aspect have interesting geometric, physical, chemical and mechanical characteristics favoring their valorization in concrete.
\end{abstract}

Keywords: characterization, slag, zellidja, valorization, civil engineering.

\section{INTRODUCTION}

For a long time, the Moroccan mining industry has been one of the main engines of economic development. The subsoil of the country is known for its great wealth of varied mineral resources distributed throughout the kingdom. The most mining exploitations include phosphate, coal, lead, iron, zinc, copper and nickel.

The Moroccan mining sector contributes $10 \%$ of gross domestic product (GDP) with a total production of 28.92 million tons (Boursenews, 2017).The Zellidja Lead Smelter Company (ZLSC) situated in the East (approximately 16 $\mathrm{Km}$ west of Touissit and $32 \mathrm{Km}$ south of Oujda) was the only lead smelter in Morocco. It represented an investment of 50 million euros and a processing capacity of 160000 tons per year of lead concentrate (SFPZ, 2010). In addition to the production of pure lead, the ZLSC also produced fine silver, copper matte, antimonial lead oxide and triple concentrate alloys. Most of its production was exported to foreign markets: Europe, America, North Africa and Middle East.

During these years of activity and until its definitive cessation in September 2012, the Zellidja Lead Smelter Company generated an estimated three million tons of slag covering a total area of $96335 \mathrm{~m}^{2}$, trapped between the back of the foundry and the Oued El Heimer watercourse. This quantity of slag was calculated by Autocad Civil after exporting a $2 \mathrm{D}$ image taken by Google Maps (Figure 1).

In Morocco, no management plan for the abandonment of old mining sites has been put in place (Rabei et al., 2014). For this reason, the Ministry of Energy, Mines and Sustainable Development launched a workshop on April 4, 2018 to 


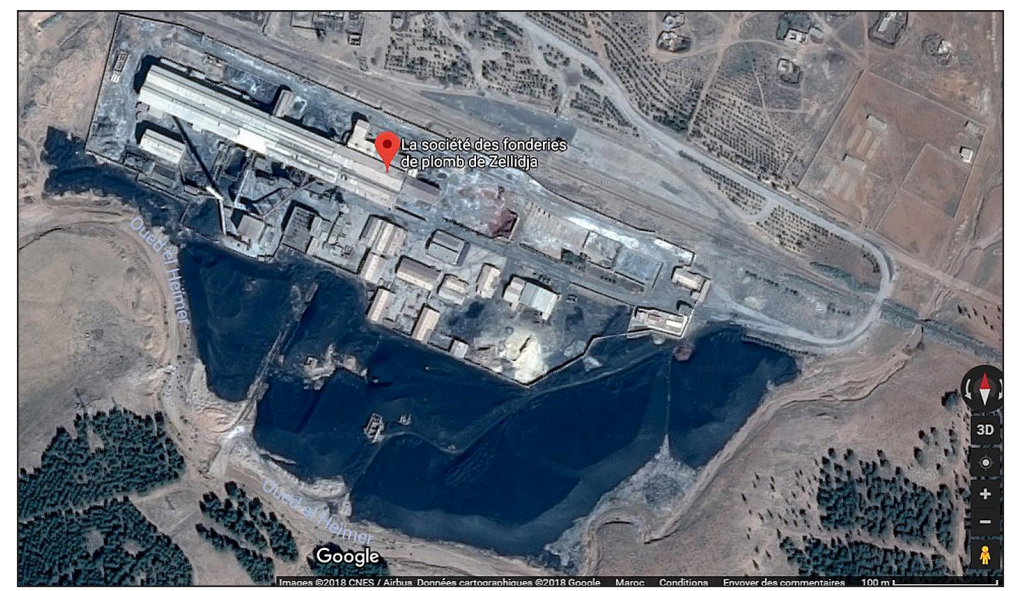

Figure 1. Satellite image of the storage site of the Zellidja lead smelter company

start the study pertaining to the preparation of an action plan for the valorization of mining wastes in Morocco (HIBAPRESS, 2018). This ministerial decision prompted several researchers to find adequate solutions to dispose of these huge stocks of tailings. The reuse of the latter as an alternative raw material in building materials is a promising environmental solution (Taha, 2017). Indeed, recent studies showed that fired bricks can be made by substituting the natural clay with several types of by-products. The substitution rate for clay is $30 \%$ of calamine and can reach $100 \%$ for coal sterile (Taha, 2017). Another study proved the possibility of using mining wastes of TouissitBoubker (Morocco) as mortar aggregates, it was also demonstrated that their incorporation into the cementitious matrix tends to stabilize these materials as well as limit the release of $\mathrm{Pb}$ and $\mathrm{Zn}$ (Rabei et al., 2014). Furthermore, it was shown that the addition of coal waste with the heat treatment results in a remarkably light and well-insulating mortar due to the increase in porosity that reduces the speed of sound (Addou et al., 2017). The reuse of base-metal tailings with low sulfide content and relatively minor concentrations of residual metals of $\mathrm{As}, \mathrm{Cr}, \mathrm{Pb}$ and $\mathrm{Zn}$ generates mortars with good mechanical and durability performances (Argane et al., 2015). Other by-products, such as coal ash and steel slag, have been valorized in the road sector; this study confirmed that their use as a base course is a very economical alternative solution compared with the conventional variant (El Alami et al., 2011). The possibility of using industrial by-products as integral substitutes of the natural aggregate in the production of cement bound granular materials for road foundations was also verified (Pasetto et al., 2015). In addition, utilization of granulated lead slag as a structural material in roads constructions is suitable under certain conditions (material for road base (subbase) under a waterproof coating such as asphalt, at least 0.5 meter above the phreatic water level) (Buzatu et al., 2015). Finally, utilization of steel slag as coarse aggregate substitute in surface courses appeared technically appropriate and could enhance the engineering properties of asphalt mixtures (Chen et al., 2016).

This study is the subject of a complete characterization of slag taken from the storage site of the Zellidja lead smelters company (Figure 2) in order to identify the most appropriate method of their valorization in civil engineering.

\section{MATERIALS AND METHODS}

\section{Materials}

The Zellidja slag was derived from the extraction process of pure lead. After the preparation phase, consisting of the incorporation of agent of melting and raw material, lead sulphides $(\mathrm{PbS})$ were transformed into lead oxides $(\mathrm{PbO})$ after passing the set of agent and raw material through an elevated temperature fixed at $900^{\circ} \mathrm{C}$. The resulting oxides were, alternately with the coke, loaded into a blast furnace, the temperature of which reached $907^{\circ} \mathrm{C}$. The slag was then separated from the lead by densimetric difference. It was cooled, blasted by a water current under pressure and deposited on the periphery of the factory.

The samples were collected during a visit to the Zellidja storage site, which was performed on November 9, 2016 in four locations varied by their GPS coordinates (Table 1). In the laboratory, the test samples were obtained using adjustable 


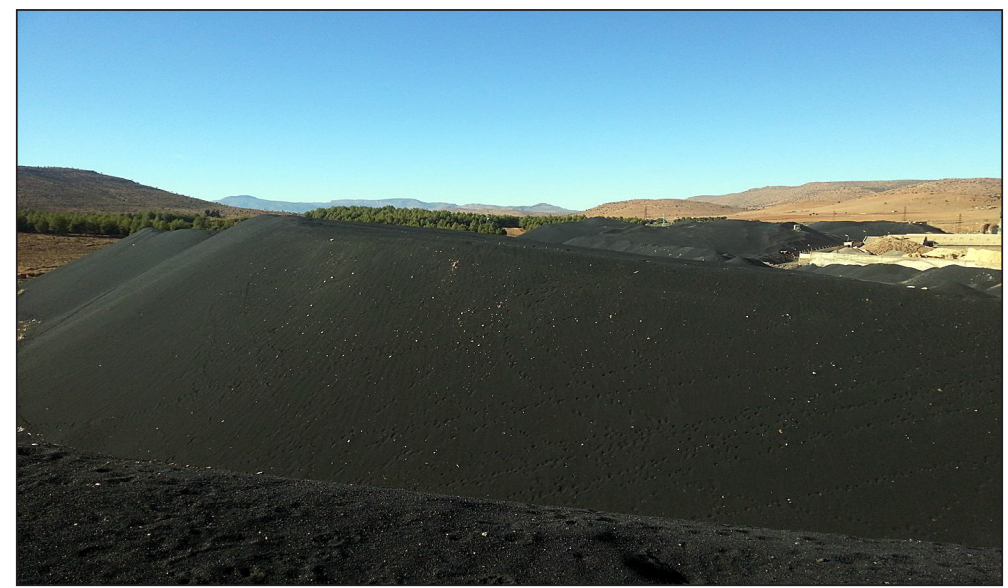

Figure 2. Photo of the storage site of the Zellidja lead smelter company (Ph. R. Moussaoui, 2016)

Table 1. Geographical coordinates of sample collection points.

\begin{tabular}{|c|c|c|c|}
\hline \multirow{2}{*}{ Sample } & \multirow{2}{*}{ Site } & N & GPS coordinates \\
\cline { 3 - 4 } & & $34^{\circ} 26^{\prime} 54.8^{\prime \prime}$ & $001^{\circ} 53^{\prime} 51.5$ \\
\hline P1 & Oued El Heimer & $34^{\circ} 26^{\prime} 53.4^{\prime \prime}$ & $001^{\circ} 53^{\prime} 51.6$ \\
\hline P2 & Oued El Heimer & $34^{\circ} 26^{\prime} 51.6^{\prime \prime}$ & $001^{\circ} 53^{\prime} 51.9$ \\
\hline P3 & Oued El Heimer & $34^{\circ} 26^{\prime} 52.1^{\prime \prime}$ & $001^{\circ} 53^{\prime} 59.0$ \\
\hline P4 & Oued El Heimer &
\end{tabular}

sample dividers homogenizing and subdividing the material into more representative parts.

\section{Characterization of Zellidja lead Smelter Company slag}

The Zellidja slag was characterized in accordance with the Moroccan standards. The particle size distribution of the sample was obtained according to NM 10.1.700 (SNIMA, 2008a). The cleanliness of slag is evaluated using the sand equivalent test and the methylene blue test in accordance with NM 10.1.147 (SNIMA, 1995a) and NM EN 933-9 (IMANOR, 2017a). The consistency of the sample was evaluated by the Atterberg Limit test according to NM 13.1.007 (SNIMA, 1998). The hardness of slag was determined by Micro-Deval test and sand friability test in accordance with NM EN 1097-1 (IMANOR, 2011a) and NM 10.1.903 (IMANOR, 2017d). Evaluating the compaction conditions of the sample was the subject of the Proctor test according to NM 13.1.023 (SNIMA, 1999). The punching resistance was the subject of immediate and post-immersion California Bearing Ratio (CBR) in accordance with NM 13.1.128 (IMANOR, 2011b). The chemical composition of slag was determined by an X-ray spectrometer (XRF), while the mineralogical composition was obtained by X-ray Diffraction (XRD-Powder). The Inductively Coupled Plasma (ICP) was employed to discover the percentages of heavy metals in slag.

\section{RESULTS}

\section{Geometric characteristics}

\section{General appearance}

The visual observation of the ZLSC slag (Figure 3 ) indicates that it consists of medium to more or less fine grains, of a blackish grey and bright color.

\section{External shape}

The Zellidja slag is characterized by a flattening coefficient of $14.54 \%$ (Table 2). Therefore, it is an aggregate with a more or less spherical external shape.

The observation of the samples using a binocular stereo microscope revealed a diversity of external shapes (Figure 4). Three shapes were distinguished: spherical shape (Figure 5), needle and stick shape (Figure 6) and irregular shape (Figure 7). 


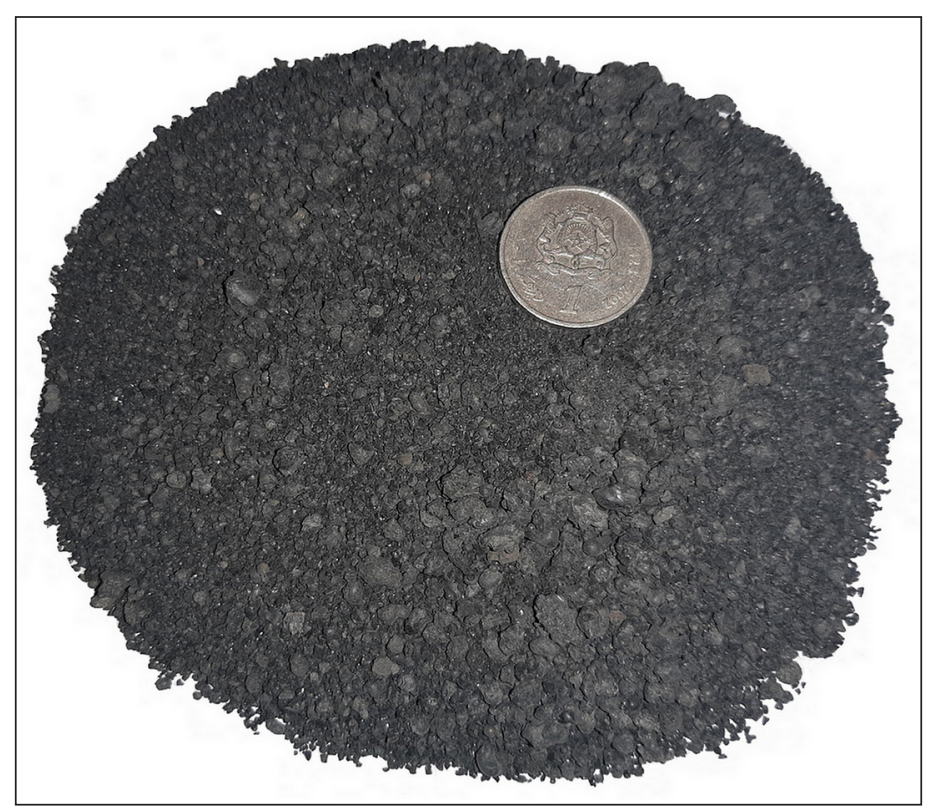

Figure 3. Visual apperance of the ZLSC slag (Ph. R. Moussaoui, 2019)

Table 2. Flattening coefficient of the ZLSC slag

\begin{tabular}{|c|c|c|c|c|}
\hline \multicolumn{2}{|c|}{ Sieving on test sieves } & \multicolumn{3}{|c|}{ Sieving on grid sieves } \\
\hline $\begin{array}{l}\text { Elementary aggregate } d_{i} / \\
\qquad D_{i}(\mathrm{~mm})\end{array}$ & $\begin{array}{c}\text { Mass }\left(R_{i}\right) \text { of the } \\
\text { elementary aggregate } \\
d_{i} / D_{i}(g)\end{array}$ & $\begin{array}{l}\text { Nominal spacing of } \\
\text { grid slots }(\mathrm{mm})\end{array}$ & $\begin{array}{l}\text { Passing on a grid } \\
\mathrm{mi} \\
(\mathrm{g})\end{array}$ & $\begin{array}{c}A_{i}=\underset{\left(m_{i} / R_{i}\right)}{(\%)} \times 100 \\
(\%)\end{array}$ \\
\hline $10 / 12.5$ & 0 & 6.3 & 0 & 0 \\
\hline $8 / 10$ & 0 & 5 & 0 & 0 \\
\hline $6.3 / 8$ & 2 & 4 & 0 & 0 \\
\hline $5 / 6.3$ & 3 & 3.15 & 1 & 33 \\
\hline $4 / 5$ & 50 & 2.5 & 7 & 14 \\
\hline \multicolumn{2}{|c|}{$M_{1}=\Sigma R_{i}=55 \mathrm{~g}$} & \multicolumn{2}{|c|}{$M_{2}=\Sigma m_{i}=8 \mathrm{~g}$} & $\begin{aligned} A= & \left(M_{2} / M_{1}\right) \times 100 \\
& =14.54 \%\end{aligned}$ \\
\hline
\end{tabular}

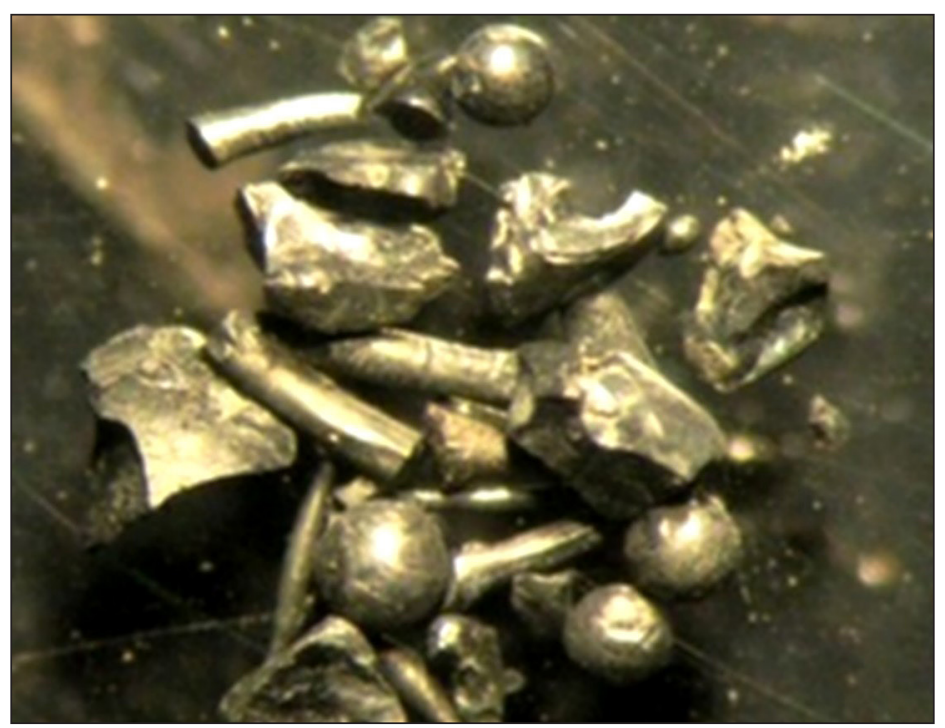

Figure 4. Shape of the ZLSC slag using a binocular stereo microscope (9.3 x 12 Magnification) 


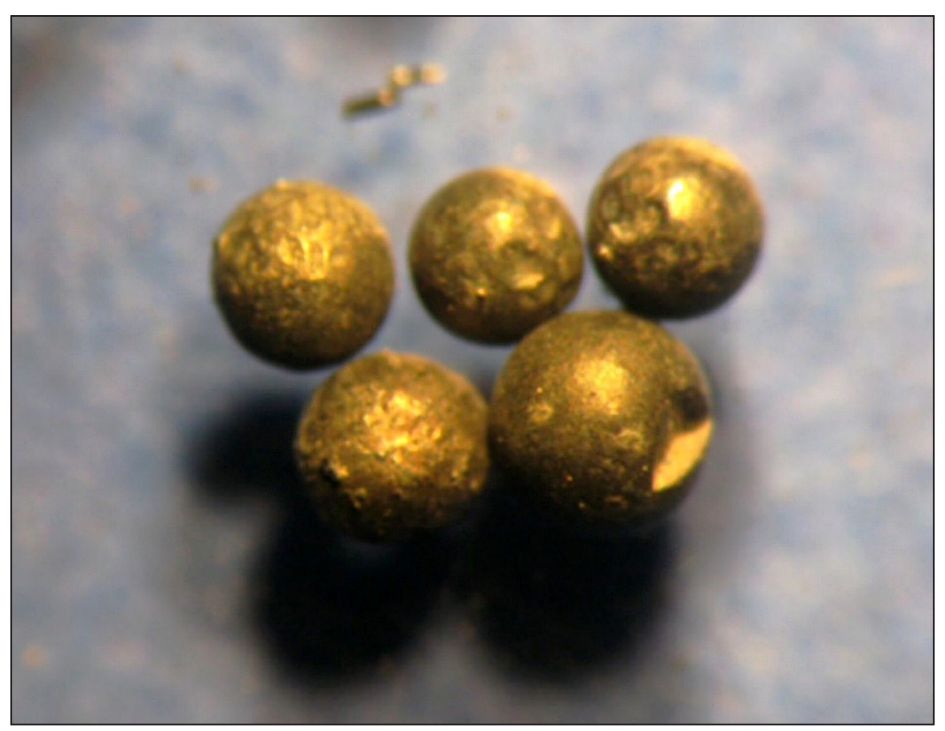

Figure 5. Slag of the ZLSC with spherical shape (7.4 x 12 Magnification)

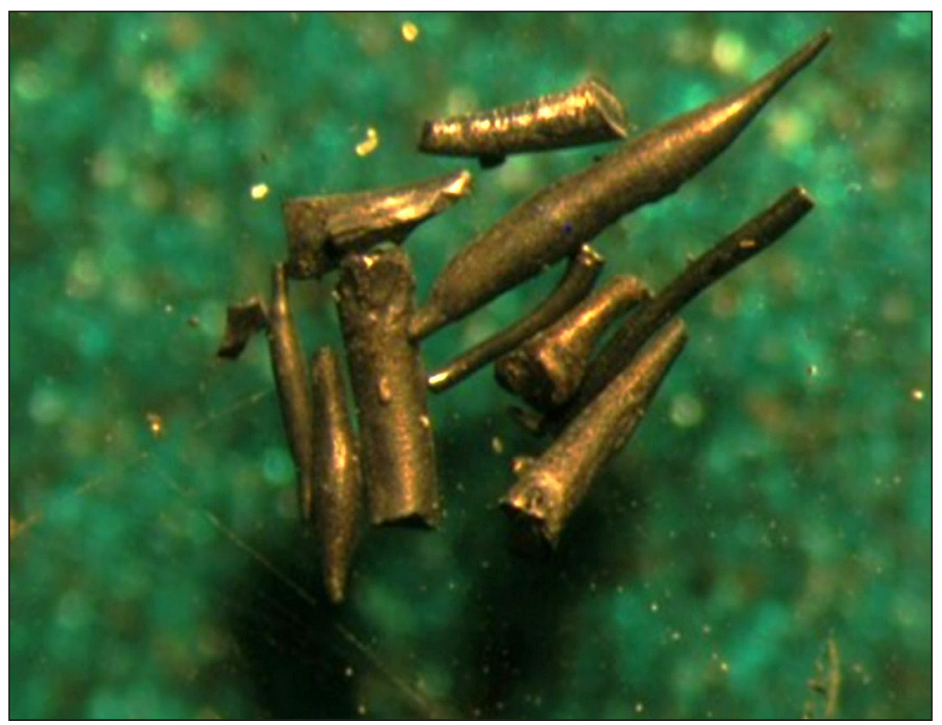

Figure 6. Slag of the ZLSC with Needle and Stick shape (12 x 12 Magnification)

\section{Granulometry}

The granulometric curve of the samples studied (Figure 8) shows that the Zellidja slag is in the granular class $0 / 10 \mathrm{~mm}$. The distribution of grains is similar to that of a sandy material with a dominance of $67.94 \%$ medium sand.

\section{Physical characteristics}

\section{Water absorption coefficient}

Taking into consideration the results of the geometric characterization, we calculated the water absorption coefficient of the ZLSC slag in accordance with NM 10.1.149 (SNIMA, 1995b). The result of this test is $0.32 \%$. The latter showes that the ZLSC slag has a low absorption percentage.

\section{True density and bulk density}

The Zellidja slag is characterized in the standard state of temperature and pressure by a true density of $3,50 \mathrm{~g} / \mathrm{cm}^{3}$ and by a bulk density of $2,02 \mathrm{~g} / \mathrm{cm}^{3}$. These values calculated according to NM EN 1097-6 (IMANOR, 2017c) and NM EN 1097-3 (IMANOR, 2017b) are high compared to those of natural sands $\left(2.69 \mathrm{~g} / \mathrm{cm}^{3}\right.$ for true density and $1.40 \mathrm{~g} / \mathrm{cm}^{3}$ for bulk density (Rabei et al., 2014)). 


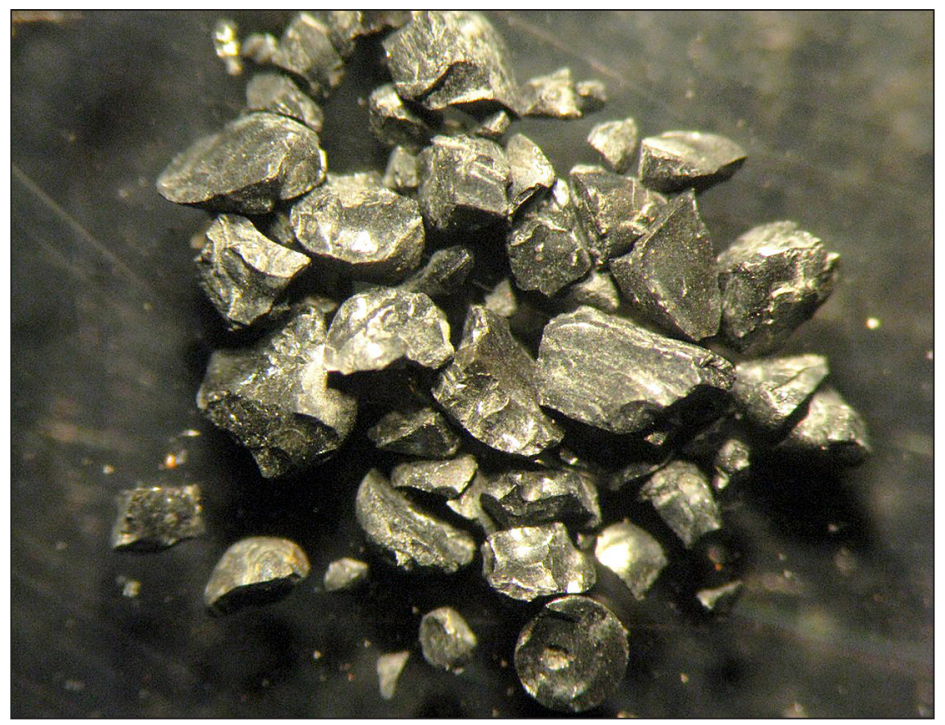

Figure 7. Slag of the ZLSC with irregular shape (6 x 12 Magnification)

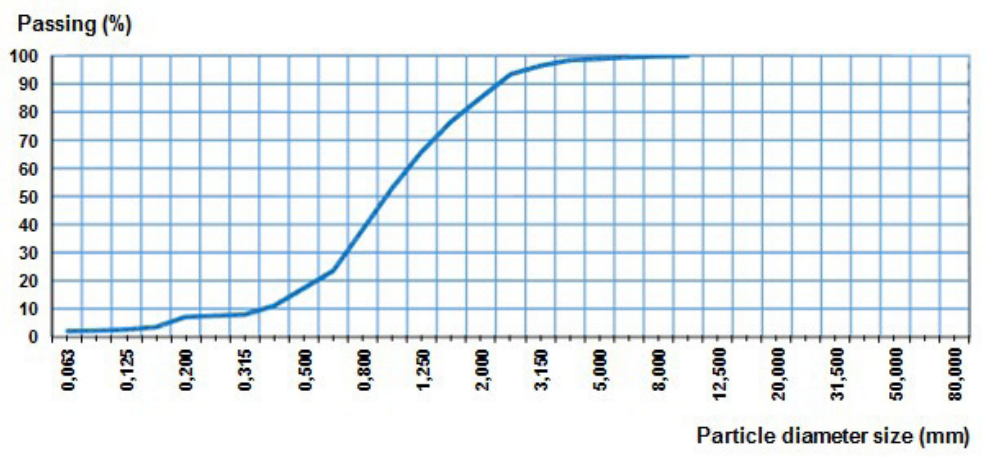

Figure 8. Granulometric curve of the ZLSC slag

\section{Cleanliness}

The cleanliness of the ZLSC slag is evaluated by the sand equivalent test and the methylene blue test. The results obtained show that it is a very clean material with moderate clay activity due to its low content of fine elements $(\mathrm{d}<63 \mu \mathrm{m})$. The sand equivalent value obtained is $90 \%$. This percentage represents a high index of cleanliness of these by-products. The methylene blue value, set at $0.20 \mathrm{ml} / \mathrm{g}$, indicated the low clay activity of slag.

\section{Chemical characteristics}

\section{Chemical composition}

The chemical composition of the ZLSC slag (Table 3) was determined by means of the X-ray fluorescence $(\mathrm{XRF})$. The results show that the Zellidja slag is rich in $\mathrm{Fe}_{2} \mathrm{O}_{3}, \mathrm{SiO}_{2}$ and $\mathrm{CaO}$. The sum of the percentages of these chemical elements approaches to $80 \%$. The moderate concentration of $\mathrm{CaO}$ (18.99\%) explains the low pozzolanic reaction observed during humidification of the material.

\section{Heavy metal content}

Due to their possible toxicological impact and in order to ensure the degree of contamination of the environment due to their storage near of Oued El Heimer, the ZLSC slag was analyzed for determination of heavy metal content using the technique of Inductively Coupled Plasma (ICP). The results of this technique are presented in table 4. It can be observed these by-products are characterized by high $\mathrm{Zn}, \mathrm{Pb}$ and $\mathrm{Cu}$ content. The high dosage of $\mathrm{Zn}$ can be explained by partial vaporization followed by a condensation of the $\mathrm{Zn}$ released during the fusion of $\mathrm{Pb}$ ores (Deneele, 2002). 
Table 3. Chemical composition of the ZLSC slag

\begin{tabular}{|c|c|}
\hline Chemical element & Concentration (\%) \\
\hline $\mathrm{Al}_{2} \mathrm{O}_{3}$ & 4.28 \\
\hline $\mathrm{CaO}$ & 18.99 \\
\hline $\mathrm{CuO}$ & 0.41 \\
\hline $\mathrm{Fe}_{2} \mathrm{O}_{3}$ & 31.09 \\
\hline $\mathrm{K}_{2} \mathrm{O}$ & 0.59 \\
\hline $\mathrm{MgO}$ & 3.24 \\
\hline $\mathrm{MnO}$ & 1.23 \\
\hline $\mathrm{Na}_{2} \mathrm{O}$ & 0.33 \\
\hline $\mathrm{P}_{2} \mathrm{O}_{5}$ & 0.04 \\
\hline $\mathrm{PbO}$ & 1.06 \\
\hline $\mathrm{S}$ & 2.07 \\
\hline $\mathrm{SiO}$ & 29.57 \\
\hline $\mathrm{TiO}_{2}$ & 0.26 \\
\hline $\mathrm{ZnO}$ & 4.66 \\
\hline $\mathrm{PF}$ & 1.73 \\
\hline $\mathrm{Total}$ & 99.55 \\
\hline
\end{tabular}

Table 4. Heavy metal content of the ZLSC slag

\begin{tabular}{|c|c|}
\hline Chemical element & Content (ppm) \\
\hline $\mathrm{Ag}$ & 14 \\
\hline $\mathrm{As}$ & 25 \\
\hline $\mathrm{Cd}$ & 41 \\
\hline $\mathrm{Co}$ & 78 \\
\hline $\mathrm{Cr}$ & 235 \\
\hline $\mathrm{Cu}$ & 3198 \\
\hline $\mathrm{Mo}$ & 186 \\
\hline $\mathrm{Pb}$ & 9859 \\
\hline $\mathrm{Sb}$ & 27 \\
\hline $\mathrm{Sr}$ & 529 \\
\hline $\mathrm{V}$ & 117 \\
\hline $\mathrm{Y}$ & 20 \\
\hline $\mathrm{Zn}$ & 37400 \\
\hline
\end{tabular}

\section{Mineralogical composition}

The mineralogical composition of the ZLSC slag (Figure 9) was determined by means of the X-ray diffraction (DRX- Powder). The diffractogram shows the dominance of two mineralogical phases, Quartz $\left(\mathrm{SiO}_{2}\right)$ and Ferrous Oxide $(\mathrm{FeO})$.

\section{Mechanical characteristics}

\section{Resistance to wear}

The resistance to wear in the presence of water characterizing the sample having class of 4-6.3 $\mathrm{mm}$ was measured by the Micro Deval test. The Micro Deval coefficient $\left(\mathrm{M}_{\mathrm{DE}}\right)$ of the ZLSC slag is $45\left(M_{D E}=45\right)$. This result revealed the mediocre hardness of our sample.

\section{Resistance to fragmentation}

The friability test of slag is performed on the $0.2-2 \mathrm{~mm}$ fraction. The friability coefficient obtained, fixed at $14 \%(\mathrm{Fs}=14 \%)$, indicated a high and very significant resistance to friability of the ZLSC slag.

\section{Compaction}

The optimal slag compaction characteristics were determined by the modified Proctor test, after sieving to $20 \mathrm{~mm}$, humidification, mixing and compaction (Figure 10).

The table 5 and figure 11 below show the variation in dry density depending on the water content. The results show that the ZLSC slag reached their maximum density at $2.39 \mathrm{~g} / \mathrm{cm}^{3}$ for relatively low water content fixed to $0.24 \%$. This asserts that our sample does not require enough water to reach its maximum density.

\section{Bearing capacity}

The characterization of an elaborated soil or material as a support or constituent of a pavement structure requires the determination of its resistance to punching, thus evaluated by the immediate California Bearing Ratio Index ( $\left.\mathrm{I} . \mathrm{CBR}_{\text {immediate }}\right)$ and the California Bearing Ratio Index after immersion (I. CBR after immersion ).

\section{Immediate CBR Index}

The sample compacted in a modified Proctor mold was introduced into the automatic CBR press in order to execute the puncture test. Three tests were realized to achieve a significant result (Table 6). The immediate CBR index (I.CBR immediate) for the ZLSC slag was set at $3.41 \%$. Therefore, it is a material with a shortterm bearing capacity level of $\mathrm{St}_{0}$.

\section{CBR index after immersion}

Three other CBR molds were immersed for four days before beginning the puncture test. In order to obtain a representative result, punching tests were realized three times (Table 7). The CBR index after immersion is $5.62 \%$, which exceeds the immediate CBR index. This increase of bearing capacity after immersion remains an advantage despite the rate of increase. 


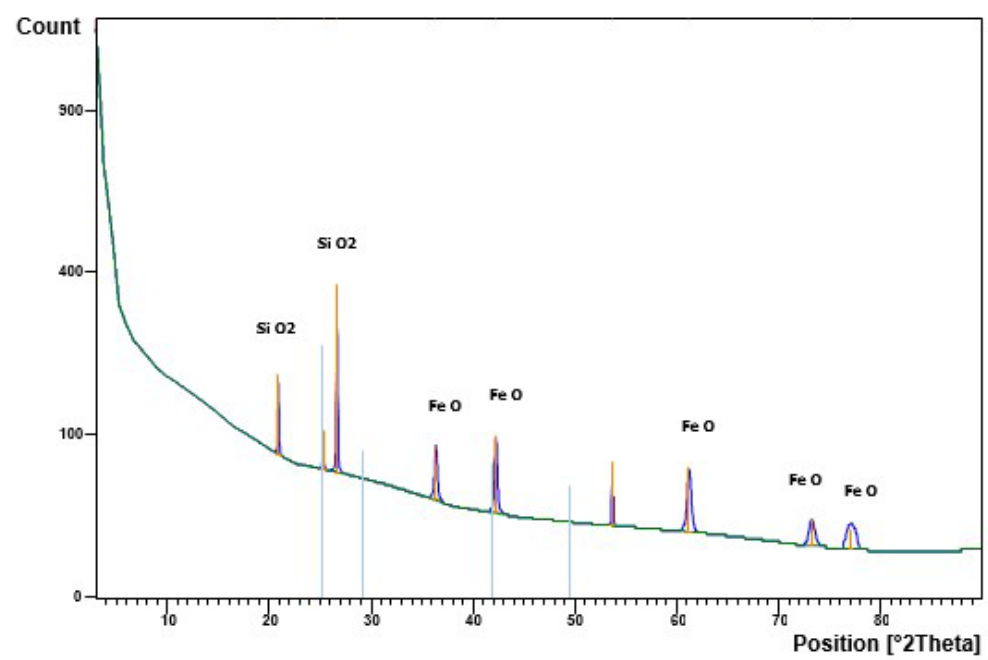

Figure 9. Mineralogical composition of the ZLSC slag.

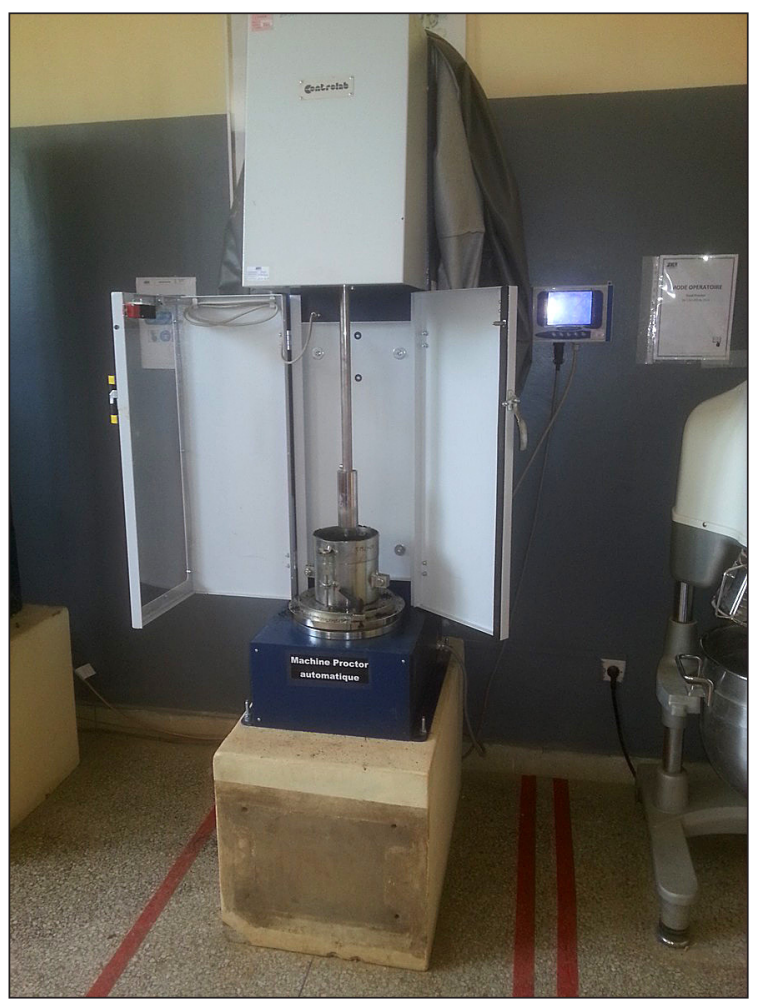

Figure 10. Compaction of the material in the automatic Proctor machine (Ph. R. Moussaoui, 2018).

\section{DISCUSSION}

The analysis of the results obtained from this characterization guides us with two possibilities for valorization of the ZLSC slag in civil engineering. The first proposal is the integration of these by-products into the pavement structure with the incorporation of another material with high hardness. The second proposal is the use of these tailings in the formulation of concrete.

\section{Valorization of the ZLSC slag in pavement structure}

The use of the ZLSC slag leads to several valorization proposals: in the surface course, base course and sub-base course. Taking into account the results of this characterization, the proposed of valorization of these by-products in the base and sub-base courses will be difficult to apply because of the non-conformity of the grading range of the slag studied to the grading range of the aggregates recommended in the Moroccan catalogue of standard new pavement structures (DRCR, 1995).

Despite the resemblance of the grading range of the ZLSC slag with that recommended for the surface course, the grain size of slag studied is not suitable for use in asphalt due to passing by $6 \mathrm{~mm}$ and $2 \mathrm{~mm}$ sieves exceeding $80 \%$ and $45 \%$, respectively. As well as passing sieve size $0.08 \mathrm{~mm}$ are lesser than $5 \%$. These by-products are characterized by a Micro-Deval coefficient $\left(\mathrm{M}_{\mathrm{DE}}\right)$ set at $45 \%$. However, the maximum value of the MDE coefficient of aggregates used in asphalt must not exceed $20 \%$. Since the sand equivalent coefficient of the ZLSC slag $(E S=90 \%)$ exceedes $40 \%$ recommended for conventional aggregates, then the cleanliness condition was verified. Therefore, the use of the Zellidja slag as surface course is unfeasible due to inconformity of grain size and insufficient hardness.

\section{Valorization of the ZLSC slag in concrete}

In order to ensure the feasibility of using slag of the ZLSC in concrete, it is necessary to verify 
Table 5. Variation of the dry density of the ZLSC slag compacted at different water content

\begin{tabular}{|c|c|c|}
\hline Point & $\begin{array}{c}\text { Water content } \\
\text { W }(\%)\end{array}$ & $\begin{array}{c}\text { Dry density } \\
Y_{d}\left(\mathrm{~g} / \mathrm{cm}^{3}\right)\end{array}$ \\
\hline 1 & 0.007 & 2.37 \\
\hline 2 & 0.125 & 2.38 \\
\hline 3 & 0.250 & 2.40 \\
\hline 4 & 0.375 & 2.36 \\
\hline 5 & 0.500 & 2.33 \\
\hline
\end{tabular}

the conformity of the aggregate specifications indicated in the Moroccan standard NM 10.1.271 (SNIMA, 2008b) and in the French standard NF EN 12620+A1 (AFNOR, 2008) with those obtained during this characterization.

The study of aggregate granularity in accordance with the above-mentioned standards requires the subdivision of the aggregate into three granular classes: sand, gravillon and gravel. All general grain size characteristics were verified in accordance with the applicable standards (Table 8). Due to the poorness of our material in fine elements, it is necessary to correct the grading rang of slag with incorporation of elements lesser than $2 \mathrm{~mm}$. The fine content of the ZLSC slag (Table 9) is of category $f_{3}$ (total content less than $3 \%$ for the three granular classes), so they are non-toxic fines.
The comparison of the true and bulk density of the ZLSC slag with those of conventional aggregates shows that these by-products have a high density that encourages their valorization in concrete. In order to prevent problems of reinforcement corrosion and concrete swelling, it is essential to ensure the chloride and sulphide contents of the aggregates. However, the chloride content can be abandoned for non-reinforced concrete (blinding concrete, filler concrete and concrete foundation). The sulfur content of the ZLSC slag was $2.07 \%$, this value exceeds the limit tolerated for concrete set at $1 \%$. Therefore, it is necessary to carry out the treatment of the ZLSC slag before its use in concrete.

\section{CONCLUSION}

The aim of this research work was the complete characterization of the Zellidja Lead Smelter Company (ZLSC) slag in order to study the possibilities of its valorization in civil engineering. The main results obtained are:

- The ZLSC slag constitutes blackish grey and bright grains, with a variety of external shapes (spherical, needle, stick and irregular).

- The granular class of ZLSC is set at 0/10 mm; the granulometric curve of these tailings is

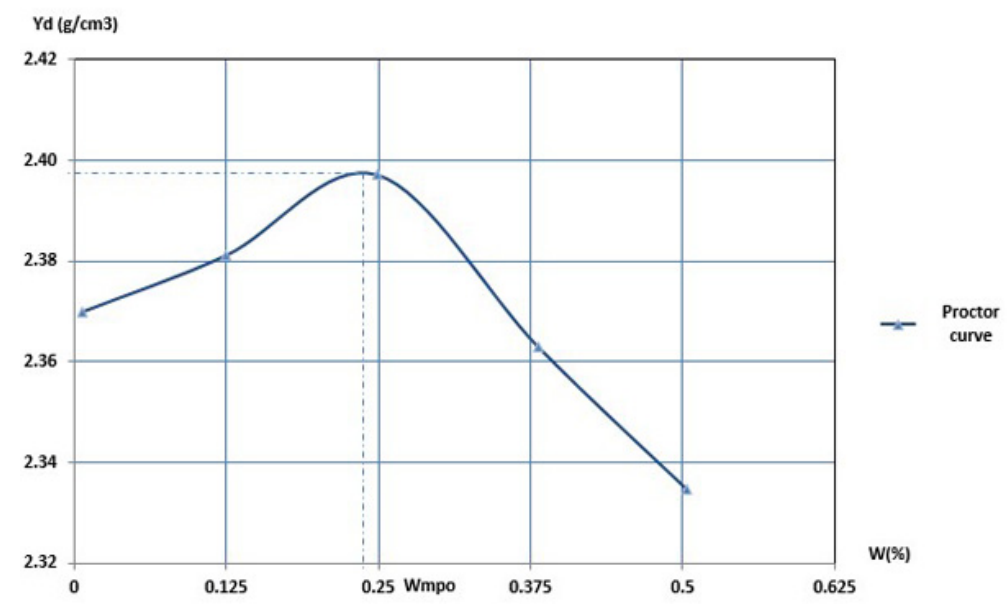

Figure 11. Modified Proctor curve of the ZLSC slag

Table 6. Immediate CBR Index

\begin{tabular}{|c|c|c|c|}
\hline Test & $\begin{array}{c}\text { I.CBR } \\
\begin{array}{c}\text { immediat at } 2.5 \mathrm{~mm} \\
(\%)\end{array}\end{array}$ & $\begin{array}{c}\text { I.CBR }_{\text {immediat at } 5 \mathrm{~mm}} \\
(\%)\end{array}$ & $\begin{array}{c}\text { I.CBR } \\
(\%)\end{array}$ \\
\hline 1 & 2.70 & 3.21 & 3.21 \\
\hline 2 & 2.85 & 3.41 & 3.41 \\
\hline 3 & 2.77 & 3.41 & 3.41 \\
\hline
\end{tabular}


Table 7. CBR Index after immersion

\begin{tabular}{|c|c|c|c|}
\hline Test & $\begin{array}{c}\text { I.CBR } \\
\text { after immersion at } 2.5 \mathrm{~mm} \\
(\%)\end{array}$ & $\begin{array}{c}\text { I.CBR } \\
\text { after immersion at } 5 \mathrm{~mm} \\
(\%)\end{array}$ & $\begin{array}{c}\text { I.CBR }_{\text {after immersion }} \\
(\%)\end{array}$ \\
\hline 1 & 4.49 & 5.62 & 5.62 \\
\hline 2 & 3.37 & 3.91 & 3.91 \\
\hline 3 & 3.15 & 3.81 & 3.91 \\
\hline
\end{tabular}

Table 8. Granularity characteristics of the ZLSC slag

\begin{tabular}{|c|c|c|c|c|c|c|c|}
\hline \multirow{2}{*}{ Aggregate } & \multirow{2}{*}{ Dimensions } & \multicolumn{5}{|c|}{ Mass of passing (\%) } & \multirow{2}{*}{ Category } \\
\hline & & $2 \mathrm{D}$ & $1.4 \mathrm{D}$ & $\mathrm{D}$ & $d$ & $\mathrm{~d} / 2$ & \\
\hline Gravillon & $\begin{array}{c}\mathrm{d}=2 \mathrm{~mm} \\
\mathrm{D}=10 \mathrm{~mm}\end{array}$ & $\begin{array}{c}100 \\
\text { Verified } \\
\text { condition }\end{array}$ & $\begin{array}{c}100 \\
\text { Verified } \\
\text { condition }\end{array}$ & $\begin{array}{c}98.25 \\
\text { Verified } \\
\text { condition }\end{array}$ & $\begin{array}{c}2.95 \\
\text { Verified } \\
\text { condition }\end{array}$ & $\begin{array}{c}0.70 \\
\text { Verified } \\
\text { condition }\end{array}$ & $G_{C} 85 / 20$ \\
\hline Sand & $\begin{array}{l}\mathrm{d}=0 \mathrm{~mm} \\
\mathrm{D}=4 \mathrm{~mm}\end{array}$ & $\begin{array}{c}100 \\
\text { Verified } \\
\text { condition }\end{array}$ & $\begin{array}{c}100 \\
\text { Verified } \\
\text { condition }\end{array}$ & $\begin{array}{c}99 \\
\text { Verified } \\
\text { condition }\end{array}$ & - & - & $G_{F} 85$ \\
\hline Gravel & $\begin{array}{c}\mathrm{d}=0 \mathrm{~mm} \\
\mathrm{D}=10 \mathrm{~mm}\end{array}$ & $\begin{array}{c}100 \\
\text { Verified } \\
\text { condition }\end{array}$ & $\begin{array}{c}100 \\
\text { Verified } \\
\text { condition }\end{array}$ & $\begin{array}{c}99 \\
\text { Verified } \\
\text { condition }\end{array}$ & - & - & $\mathrm{G}_{\mathrm{A}} 90$ \\
\hline
\end{tabular}

Table 9. Fines content of the ZLSC slag

\begin{tabular}{|c|c|c|}
\hline Aggregate & $\begin{array}{c}\text { Mass of passing through } \\
0.063 \mathrm{~mm} \text { sieve size }(\%)\end{array}$ & Category \\
\hline Gravillon & 2.18 & $\mathrm{f}_{3}$ \\
\hline Sand & 0.25 & $\mathrm{f}_{3}$ \\
\hline Gravel & 1.58 & $\mathrm{f}_{3}$ \\
\hline
\end{tabular}

rich in fine elements, low in large elements (curve similar to that of a sandy material with a dominance of $67.94 \%$ of medium sand).

- The ZLSC slag is characterized by their low water catchment capacities (water absorption coefficient set at $0.32 \%$ ).

- The true and bulk densities of the ZLSC slag are high compared to those of natural aggregates.

- The ZLSC slag is very clean, with moderate clay activity.

- The chemical composition of the ZLSC slag showed the presence of high concentrations of $\mathrm{Fe}_{2} \mathrm{O}_{3}, \mathrm{SiO}_{2}$ and $\mathrm{CaO}$.

- The mineralogical composition of these byproducts is marked by the dominance of the mineralogical phases of $\mathrm{SiO}_{2}$ and $\mathrm{FeO}$.

- The ZLSC slag has a mediocre resistance to wear $\left(\mathrm{M}_{\mathrm{DE}}=45 \%\right)$ and a high fragmentation resistance $\left(\mathrm{F}_{\mathrm{S}}=14 \%\right)$. This result no longer encourages their use in pavement structure.

- The modified Proctor optimum of the ZLSC slag is $2.39 \mathrm{~g} / \mathrm{cm}^{3}$ obtained for relatively low water content $\left(\mathrm{W}_{\text {mpo }}\right)$ not exceeding $0.24 \%$.

- This research will be followed by a series of tests to ensure the feasibility of valorization of the ZLSC slag in concrete.

\section{Acknowledgements}

Our thanks go especially to the National Centre for Road Studies and Research (Rabat, Morocco) which offered us the opportunity to perform the majority of tests in its laboratory. Our thanks also go to the Zellidja Lead Smelters Company (Oued El Heimer, Morocco), the laboratory of experts in Geotechnics, Buildings and Public Works (Casablanca, Morocco) and to the National Office of Hydrocarbons and Mines (Rabat, Morocco) for their collaboration.

\section{REFERENCES}

1. Addou R., Hannawi K., Agbodjan W. P. and Zenasni M. 2017. Characterization of Moroccan Coal Waste (Jerada Mine): Impact on Physical Properties of Mortars Made of Coal Waste. Journal of Materials and Environmental Science, 8(10), 3473-3482.

2. AFNOR. 2008. Granulats pour béton. NF EN 12620+A1. Association Française de Normalisation, France.

3. Argane R., Benzaazoua M., Hakkou R. and Bouamrane A. 2015. Reuse of base-metal tailings as aggregates for rendering mortars: Assessment of immobilization performances and environmental behavior. Construction and Building Materials, (96), 296-306.

4. Boursenews. 2017. Secteur minier : Une contribution de $10 \%$ au PIB selon Rabbah [online]. Available: https://www.boursenews.ma/article/actualite/ secteur-minier-une-contribution-de-10-au-pib-selon-rabbah [accessed on 7 November 2018]. 
5. Buzatu T., Talpoş E., Petrescu M. I., Ghica V. G., Iacob G. and Buzatu M. 2015. Utilization of granulated lead slag as a structural material in roads constructions. Journal of Material Cycles and Waste Management, 17(4), 707-717.

6. Chen J. S. and Wei S. H. 2016. Engineering properties and performance of asphalt mixtures incorporating steel slag. Construction and Building Materials, (128), 148-153.

7. Deneele D. 2002. Caractérisation, simulations expérimentales et thermodynamiques de l'altération de déchets vitreux: Les scories de première fusion de plomb et de zinc. Doctoral dissertation, Lille 1.

8. DRCR. 1995. Le catalogue des structures types de chaussée neuves. Direction des Routes et de la Circulation Routière, Maroc.

9. El Alami S. E. M., Monkade M., Lahlou K. and des Travaux Publics E. 2011. Valorisation d'un mélange de cendres d'une centrale thermique et de scories d'aciérie dans les chaussées routières.

10. HIBAPRESS. 2018. DD: LA VALORISATION DES DÉCHETS MINIERS AU MAROC [online]. Available: https://fr.hibapress.com/news-7999. html [accessed on 2 January 2019].

11. IMANOR. 2017a. Essais pour déterminer les caractéristiques géomètriques des granulats - Partie 9 : Qualification des fines - Essai au bleu de Méthylène. NM EN 933-9. Institut Marocain de Normalisation, Maroc.

12. IMANOR. 2011a. Essais pour déterminer les caractéristiques mécaniques et physiques des granulats - Partie 1 : détermination de la résistance à l'usure (micro-Deval). NM EN 1097-1. Institut Marocain de Normalisation, Maroc.

13. IMANOR. 2017b. Essais pour déterminer les caractéristiques mécaniques et physiques des granulats - Partie 3 : Méthode pour la détermination de la masse volumique en vrac et de la porosité intergranulaire. NM EN 1097-3. Institut Marocain de Normalisation, Maroc.

14. IMANOR. 2017c. Essais pour déterminer les caractéristiques mécaniques et physiques des granulats - Partie 6 : Détermination de la masse volumique réelle et du coefficient d'absorption d'eau. NM EN 1097-6. Institut Marocain de Normalisation, Maroc.
15. IMANOR. 2017d. Granulats - Détermination du coefficient de friabilité du sable. NM 10.1.903. Institut Marocain de Normalisation, Maroc.

16. IMANOR. 2011b. Sols : Reconnaissance et essais - Indice CBR après immersion - Indice CBR immédiat - Mesure sur échantillon compacté dans le moule CBR. NM 13.1.128. Institut Marocain de Normalisation, Maroc.

17. Pasetto M. and Baldo N. 2015. Experimental analysis of hydraulically bound mixtures made with waste foundry sand and steel slag. Materials and Structures, 48(8), 2489-2503.

18. Rabei A., Mostafa B., Ahmed B. and Rachid H. 2014. Valorisation des rejets miniers du district $\mathrm{Pb}$ zn de Touissit-Boubker (région orientale-Maroc).

19. SFPZ. 2010. Chairman's statement [online]. Available: http:/www.sfpz.ma/Chairmansstatement.htm [accessed on 14 November 2018].

20. SNIMA. 1999. Essai de reconnaissance des sols Essai Proctor. NM 13.1.023. Service de Normalisation Industrielle Marocaine, Maroc.

21. SNIMA. 1998. Essai d'identification - Détérmination des limites d'Atterberg - Limite de plasticité au rouleau - Limite de liquidité à la coupelle. NM 13.1.007. Service de Normalisation Industrielle Marocaine, Maroc.

22. SNIMA. 2008a. Essai pour déterminer les caractéristiques géomètriques des granulats - Détérmination de la granularité - Analyse granulométrique par tamisage. NM 10.1.700. Service de Normalisation Industrielle Marocaine, Maroc.

23. SNIMA. 1995a. Granulats - Equivalent de sable. NM 10.1.147. Service de Normalisation Industrielle Marocaine, Maroc.

24. SNIMA. 1995b. Granulats - Mesure des masses spécifiques - Coefficient d'absorption et teneur en eau des sables. NM 10.1.149. Service de Normalisation Industrielle Marocaine, Maroc.

25. SNIMA. 2008b. Granulats pour bétons hydrauliques - Définitions, spécifications, conformité. NM 10.1.271. Service de Normalisation Industrielle Marocaine, Maroc.

26. Taha Y. 2017. Valorisation des rejets miniers dans la fabrication de briques cuites: Évaluations technique et environnementale. Doctoral dissertation, Université du Québec en Abitibi-Témiscamingue. 